\title{
EFFECT OF RESTRICTED FEEDING AND PARTIAL WATER RENEWAL ON WATER QUALITY AND GROWTH PERFORMANCE OF NILE TILAPIA UNDER BIOFLOC CULTURE
}

\author{
(Received: 29.6.2015) \\ By \\ M.A. Elnady , R.K. Abd Elwahed and A.F. Younes \\ Animal Production Department, Faculty of Agriculture, Cairo University, Egypt.
}

\begin{abstract}
The current experiment investigated the effect of restricted feeding and partial water renewal in biofloc tank culture on growth and feed performance of Nile tilapia. The experimental work included four biofloc treatments, with two feeding levels ( 75 and 100 grams diet $/ \mathrm{m}^{3} /$ day) and two partial water renewal rates (weekly and biweekly). The control treatment was fed to satiation, with water renewal every other day. Mean values of total ammonia nitrogen (TAN) were within the acceptable range considered suitable for the cultivation of Nile tilapia $(0.6-1.02 \mathrm{mg} / \mathrm{l})$, with no significant differences observed among treatments $(\mathrm{P}>0.05)$. Nitrite concentrations ranged from 0.35 to $0.51 \mathrm{mg} / \mathrm{l}$ between treatments. The concentrations of nitrite $(\mathrm{NO} 2-\mathrm{N})$ remained within optimal levels recommended for the growth of Nile tilapia.The overall mean values of nitrate were approximately similar among treatments ranging from 29.8 to $46.0 \mathrm{mg} \mathrm{NO} 3-\mathrm{N} / 1$. The biofloc treatments were characterized during the current study by the chemotrophic stage due to the nitrification process shown by the high concentration of nitrate observed at the end of study. The accumulation of nitrite and nitrate concentrations during the experiment indicated that the nitrification process was running at optimal rates. The biofloc treatments with higher feed input had biofloc volume of $40.7-51.4 \mathrm{ml} / \mathrm{l}$ that did not differ significantly from those of the lower feed input treatments $(38.1-60.1 \mathrm{ml} / \mathrm{l})$. The increase of daily feed input did not affect biofloc volume in culture tanks due to the water renewal design. Nile tilapia reared under biofloc system had significantly lower $(\mathrm{P}<0.05)$ mean final weights $(55.8-67.9$ $\mathrm{g} /$ fish) than those reared in the control treatment $(91.4 \mathrm{~g} /$ fish). However, all the treatments had similar harvest volume ( 5.15 to $6.08 \mathrm{~kg}$ fish $/ \mathrm{m}^{3}$ ), with no significant differences among the biofloc treatments and the control treatment. This was due to the better survival rates observed in the biofloc treatments compared to the control. In spite of the differences in growth rates, the higher protein efficiency ratios (2.14- 2.59) and the better food conversion ratios (1.21 - $1.76: 1$ ) observed in the biofloc treatments indicated that it is possible to use restricted feeding when fish are raised in biofloc tanks. The biofloc treatments were more efficient in terms of feed conversion ratios and survival. Consequently, the current results suggest that in the presence of biofloc, it is possible to restrict (reduce) feeding rates from satiation to restricted feeding without affecting harvest volume or survival rate. The promoted biofloc could contribute to the nutrition and physiological health of Nile tilapia.
\end{abstract}

Key words: biofloc, restricted feeding, water renewal, Nile tilapia, efficiency, production

\section{INTRODUCTION}

Aquaculture is predicted to increase 5-folds until 2050 (FAO, 2012). To meet this growing demand, aquaculture is shifting from extensive cultivation systems to more intensive systems (Luo et al., 2013). With the intensification of aquaculture, the focus has increasingly shifted to its negative environmental and social impact (Luo et al., 2013).
These Biofloc technology depend on the living microbial biomass and particulate organic matter maintained in the water column that aid in ammonia removal via phytoplankton and bacterial uptake (Schrader et al., 2011) as well as bacterial oxidation of ammonia to nitrite and then subsequent oxidation of nitrite to nitrate during nitrification (Brune et al., 2003; Ebeling et al., 2006; Hargreaves, 2006). 
Biofloc is composed of bacteria, fungi and plankton that have high protein content (30$40 \%$ ). The size of biofloc particles ranges from 0.5 to $2.0 \mathrm{~mm}$, which could be fed to Nile tilapia and shrimp (Supono et al., 2013).

In biofloc culture, heterotrophic bacteria are exploited to convert ammonia produced in aquaculture into bacteria biomass (De Schryver and Verstraete, 2009), which could be used to feed fish, therefore increasing feed utilization (Luo et al., 2013). Nile tilapia and heterotrophic bacterial biomass are cultured in the same water volume and have already been utilized in pond culture for tilapia (Azim and little, 2008).

In biofloc technology (BFT) the growth of heterotrophic bacterial biomass is stimulated towards the conversion of the excreted ammonia waste into microbial biomass by supplementing an external carbohydrate source (i.e. molasses or sucrose). The bacterial biomass could be further used as a food source by the cultured organisms, increasing feed utilization efficiency (Ekasari $e t$ $a l .$, 2013). Therefore, these biological processes play a critical role in reducing ammonia and nitrite to levels below toxic levels that are considered growth-limiting for cultured fish (Schrader et al., 2011).

As feed is the major driving force of intensive production systems, it is important to optimize its use to improve profitability, maximize growth, and minimize potential water quality deterioration (Correia et al., 2014).

Fish culture in biofloc systems provides a potential food source for cultured animals under limited water renewal. This culture system is based on limited water use and minimal water discharge into the surrounding environment (Emerenciano et al., 2011).

Freshwater scarcity is for sure becoming a global concern due to high human population growth. The use of biofloc technology helps in water conservation. Ogello et al. (2014) indicated that a significant reduction in organic nitrogen accumulation, an increased utilization of feed protein and a reduced feed expenditure could be achieved in biofloc systems.

Intensive, recirculating tilapia, Oreochromis niloticus, biofloc systems are capable of producing the equivalent of 155 tons $/ \mathrm{ha} / \mathrm{crop}$ (Rakocy et al., 2004). Biofloc production systems treat and reuse water in tank culture (Danaher et al., 2011).

The aims of the present study were to evaluate growth performance and dietary efficiency for Nile tilapia cultured in intensive biofloc system using different feeding levels. The objective was to evaluate the best biofloc system under restricted feeding and partial water renewal conditions compared to clear water culture conditions.

\section{MATERIALS AND METHODS}

The study was conducted at The Fish Culture Research Unit, Faculty of Agriculture, Cairo University, Egypt during Spring season 2015. A static outdoor rearing system consisting of fifteen rectangular concrete tanks $(2.2$ x 1.2 x 1.0 $\mathrm{m})$ were filled with fresh water obtained from a well and were used as rearing units for Nile tilapia. Each tank had a water volume of $2.0 \mathrm{~m}^{3}$, with a constant water depth $75 \mathrm{~cm}$.

\subsection{Experimental design}

Nile tilapia Juveniles with an average initial weight of 20.0-30.0 grams/fish were distributed randomly among fifteen concrete tanks. Fish were stocked at 200 Juveniles per tank (100 Juveniles per cubic meter of water). Nile tilapia were fed floating commercial pellets $(32 \%$ crude protein), six days a week. The experiment consisted of five treatments, with three replicate tanks per treatment. Water in biofloc tanks was renewed once every one or two weeks at the rate of $50 \%$ water volume in each tank in order to reduce sludge, suspended organic matter and nitrate concentration. Artificial aeration was provided 24-hours a day in all treatments for the whole experimental period using a blower. Sucrose was dissolved in water and sprinkled over water surface in each biofloc tank at $50 \%$ of daily feed input $(\mathrm{g} / \mathrm{g})$ in order to develop biofloc and nourish heterotrophic bacteria. The experiment started 31 March 2015 and lasted 75 days. The design of the experiment was as follows:

\subsubsection{The weekly water renewal and $75 \mathrm{~g}$ diet $/ \mathrm{m}^{3} /$ day restricted feeding}

Fish were fed at 75 grams $\mathrm{diet} / \mathrm{m}^{3}$ of water volume per day, six days a week (150 grams diet/tank/day). Sucrose was added to tank water at 75 grams sucrose/tank/day. Water was partially renewed once every week at the rate of $50 \%$ of water volume in each tank .

\subsubsection{The weekly water renewal and $100 \mathrm{~g}$ $\mathrm{diet} / \mathrm{m}^{3} / \mathrm{day}$ restricted feeding}

Fish were fed at 100 grams diet $/ \mathrm{m}^{3}$ of water volume per day, six days a week (200 grams diet/tank/day). Sucrose was added to tank water at 100 grams sucrose/tank/day. Water was 
partially renewed once every week at the rate of $50 \%$ water volume in each tank.

\subsubsection{The biweekly water renewal and $75 \mathrm{~g}$ $\mathrm{diet} / \mathrm{m}^{3} /$ day restricted feeding}

Fish were fed at 75 grams diet per $\mathrm{m}^{3}$ of tank water per day, six days a week (150 grams diet/tank /day). Sucrose was added to tank water at $75 \mathrm{~g}$ sucrose/tank/day. Water were partially renewed once every two weeks at the rate of $50 \%$ water volume in each tank.

\subsubsection{The biweekly water renewal and $100 \mathrm{~g}$ $\mathrm{diet} / \mathrm{m}^{3} /$ day restricted feeding}

Fish were fed at the rate of 100 grams diet $/ \mathrm{m}^{3}$ of tank water per day, six days a week (200 grams diet/tank/day). Sucrose was added to tank water at $100 \mathrm{~g}$ sucrose/tank/day. Water were partially renewed once every two weeks at the rate of $50 \%$ water volume in each tank.

\subsubsection{The control treatment}

The control treatment employed the clear water intensive culture technique. Fish were fed at satiation which was equivalent to $125 \mathrm{~g}$ diet $/ \mathrm{m}^{3}$ of tank water/day ( $250 \mathrm{~g}$ diet/tank/day), six days a week. Water in each tank were renewed at $80 \%$ water volume every other day in order to reduce ammonia concentration and toxic metabolic products.

\subsection{Growth and feed performance}

The growth and feed performance parameters were calculated as follows:

\subsubsection{Body weight}

Individual weights of fish were measured at the start and end of the experimental period using digital balance for weight to the nearest $0.1 \mathrm{~g}$.

\subsubsection{Daily weight gain (DWG )}

DWG = (final body weight -initial body weight)/ experimental period(days).

\subsubsection{Specific growth rate (SGRW)}

$\mathrm{SGRW}=\left(\mathrm{Ln} \mathrm{W}_{\mathrm{t}}-\mathrm{Ln} \mathrm{W}_{0}\right) * 100 / \mathrm{t}$

Where $\mathrm{W}_{\mathrm{t}}$ is weight at time $\mathrm{t}, \mathrm{W}_{0}$ weight at time 0 , and $t$ is the duration of time in days.

\subsubsection{Feed conversion ratio (FCR)}

Feed efficiency was determined as the grams of dry diet consumed per gram of wet weight gain of fish.

FCR=dry weight of feed fed (g)/fish weight gain $(\mathrm{g})$.

\subsubsection{Protein efficiency ratio (PER)}

The protein efficiency ratio was calculated as the grams of wet weight gain of fish per gram of protein consumed .

PER = fish weight gain $(\mathrm{g}) /$ protein fed $(\mathrm{g})$

\subsection{Water quality parameters}

All determinations of water quality parameters were carried out according to Boyd and Tucker (1992). Water from each tank was tested once a week for all water quality parameters. Temperature and dissolved oxygen were measured by using Hanna Instrument (model 55) dissolved oxygen meter. Estimates of secchi disk visibility were made in the afternoon in each concrete tank. $\mathrm{pH}$ was measured using digital $\mathrm{pH}$ meter (Hanna instruments) at the laboratory just after water sample was collected in a container. Water column respiration rate per hour as well as per day was measured once every two weeks using 0.5 liter dark bottles where tank water loaded with biofloc were incubated for two hours. Total ammonia concentration (TAN) in tank water was measured using the indophenol method (phenate method) and colorimeter. Nitrate -nitrogen was measured using HANNA kits for nitrate (the cadmium reduction method) and a colorimeter.Nitritenitrogen was measured using the diazotizing method and colorimeter (Boyd and Tucker, 1992). Orthophosphate was measured by the ascorbic acid method using HANNA kit and colorimeter. Biofloc volume $(\mathrm{ml} / \mathrm{l})$ in each tank was measured using the Imhof cone where water loaded with biofloc were left to settle for 30 minutes (Boyd and Tucker, 1992).

\subsection{Statistical analysis}

Growth performance of the cultured fish as well as water quality parameters in culture tanks were subjected to one-way analyses of variance to determine statistical significant differences among treatments. Differences between means were assessed by Duncan multiple range test (Duncan, 1955). Statistically significant differences differences were determined by setting the aggregate type I error at $5 \%(\mathrm{p}<0.05)$ for each comparison. This statistical analysis was performed using the software package SPSS for windows, release 8.0 (SPSS, 1997).

\section{RESULTS AND DISCUSSION \\ 3.1. Water quality parameters}

Good water quality was maintained with the development of biofloc through sucrose addition at $50 \%$ of the amount of feed applied daily in each tank. The results of water quality parameters were optimal in terms of recommended levels for Nile tilapia culture as shown in Table (1).

\subsubsection{Oxygen and $\mathrm{pH}$}

In the current study, artificial aeration supplied oxygen as well as created water mixing and agitation to suspend biofloc particles. 
Table (1). Water quality of Nile tilapia tanks reared under different Biofloc conditions.

\begin{tabular}{|c|c|c|c|c|c|}
\hline \multirow[b]{2}{*}{ parameters } & \multicolumn{2}{|c|}{75 grams diet $/ \mathrm{m}^{3}$} & \multicolumn{2}{|c|}{$100 \mathrm{grams} \operatorname{diet} / \mathrm{m}^{3}$} & \multirow[b]{2}{*}{ control } \\
\hline & $\begin{array}{l}\text { Weekly } \\
\text { change }\end{array}$ & $\begin{array}{l}\text { Biweekly } \\
\text { change }\end{array}$ & $\begin{array}{l}\text { Weekly } \\
\text { change }\end{array}$ & $\begin{array}{l}\text { Biweekly } \\
\text { change }\end{array}$ & \\
\hline Water temperature $\left({ }^{\circ} \mathrm{c}\right)$ & $\begin{array}{l}24.26^{\mathrm{a}} \\
\pm 2.35 \\
\end{array}$ & $\begin{array}{l}23.84^{\mathrm{a}} \\
\pm 2.25 \\
\end{array}$ & $\begin{array}{r}23.77^{\mathrm{a}} \\
\pm 2.300 \\
\end{array}$ & $\begin{array}{l}24.08^{\mathrm{a}} \\
\pm 2.36 \\
\end{array}$ & $\begin{array}{l}24.10^{\mathrm{a}} \\
\pm 2.33 \\
\end{array}$ \\
\hline $\begin{array}{l}\text { Oxygen } \\
\text { concentration(mg/l) }\end{array}$ & $\begin{array}{r}4.38^{\mathrm{a}} \\
\pm 1.03 \\
\end{array}$ & $\begin{array}{l}4.45^{\mathrm{a}} \\
\pm 0.70 \\
\end{array}$ & $\begin{array}{l}5.21^{\mathrm{a}} \\
\pm 0.91 \\
\end{array}$ & $\begin{array}{l}4.88^{\mathrm{a}} \\
\pm 0.97 \\
\end{array}$ & $\begin{array}{r}4.44^{\mathrm{a}} \\
\pm 1.38 \\
\end{array}$ \\
\hline PH readings & $\begin{array}{r}7.74^{\mathrm{a}} \\
\pm 0.19\end{array}$ & $\begin{array}{l}7.63^{\mathrm{a}} \\
\pm 0.06\end{array}$ & $\begin{array}{l}7.77^{\mathrm{a}} \\
\pm 0.13\end{array}$ & $\begin{array}{l}7.73^{\mathrm{a}} \\
\pm 0.14\end{array}$ & $\begin{array}{l}7.65^{\mathrm{a}} \\
\pm 0.08\end{array}$ \\
\hline $\begin{array}{l}\text { Total ammonia } \\
\text { concentration(mg/l) }\end{array}$ & $\begin{array}{l}0.64^{\mathrm{a}} \\
\pm 0.83 \\
\end{array}$ & $\begin{array}{l}0.60^{\mathrm{a}} \\
\pm 0.80 \\
\end{array}$ & $\begin{array}{l}0.77^{\mathrm{a}} \\
\pm 1.00 \\
\end{array}$ & $\begin{array}{l}0.90^{\mathrm{a}} \\
\pm 1.05 \\
\end{array}$ & $\begin{array}{r}1.02^{\mathrm{a}} \\
\pm 1.58 \\
\end{array}$ \\
\hline $\begin{array}{l}\text { Nitrate-N } \\
\text { concentration } \\
(\mathrm{mg} / \mathrm{L})\end{array}$ & $\begin{array}{l}29.88^{\mathrm{b}} \\
\pm 5.31\end{array}$ & $\begin{array}{l}46.06^{\mathrm{a}} \\
\pm 7.32\end{array}$ & $\begin{array}{l}37.78^{\mathrm{ab}} \\
\pm 8.70\end{array}$ & $\begin{array}{c}37.93^{\text {ab }} \\
\pm 5.83\end{array}$ & - \\
\hline $\begin{array}{l}\text { Nitrite }-\mathrm{N} \\
\text { concentration }(\mathrm{mg} / \mathrm{l})\end{array}$ & $\begin{array}{l}0.51^{\mathrm{a}} \\
\pm 0.42\end{array}$ & $\begin{array}{l}0.39^{\mathrm{a}} \\
\pm 0.37\end{array}$ & $\begin{array}{l}0.35^{\mathrm{a}} \\
\pm 0.32\end{array}$ & $\begin{array}{l}0.46^{\mathrm{a}} \\
\pm 0.31\end{array}$ & $\begin{array}{l}0.27^{\mathrm{a}} \\
\pm 0.25\end{array}$ \\
\hline $\begin{array}{l}\operatorname{Phosphate}\left(\mathrm{PO}_{4}\right) \\
\text { concentration }(\mathrm{mg} / \mathrm{l})\end{array}$ & $\begin{array}{r}0.77^{\mathrm{a}} \\
\pm 0.44\end{array}$ & $\begin{array}{l}0.93^{\mathrm{a}} \\
\pm 0.81\end{array}$ & $\begin{array}{l}0.94^{\mathrm{a}} \\
\pm 0.68\end{array}$ & $\begin{array}{l}1.29^{\mathrm{a}} \\
\pm 0.93\end{array}$ & $\begin{array}{l}0.80^{\mathrm{a}} \\
\pm 0.52\end{array}$ \\
\hline Secchi disk $(\mathrm{cm})$ & $\begin{array}{l}11.76^{\mathrm{b}} \\
\pm 2.32\end{array}$ & $\begin{array}{l}12.30^{\mathrm{b}} \\
\pm 3.63\end{array}$ & $\begin{array}{l}11.24^{b} \\
\pm 1.93\end{array}$ & $\begin{array}{l}11.44^{\mathrm{b}} \\
\pm 3.06\end{array}$ & $\begin{array}{r}23.9^{\mathrm{a}} \\
\pm 9.60\end{array}$ \\
\hline Biofloc volume $(\mathrm{ml} / \mathrm{l})$ & $\begin{array}{l}38.16^{\mathrm{b}} \\
\pm 8.36 \\
\end{array}$ & $\begin{array}{r}60.16^{\mathrm{a}} \\
\pm 10.57 \\
\end{array}$ & $\begin{array}{l}51.41^{\mathrm{ab}} \\
\pm 12.04 \\
\end{array}$ & $\begin{array}{r}40.74^{\mathrm{b}} \\
\pm 11.88 \\
\end{array}$ & - \\
\hline $\begin{array}{l}\text { Water respiration per } \\
\text { hour }\left(\mathrm{mgO}_{2} / \mathrm{l} / \text { hour }\right)\end{array}$ & $\begin{array}{l}1.09^{\mathrm{c}} \\
\pm 0.11\end{array}$ & $\begin{array}{l}1.30^{\mathrm{b}} \\
\pm 0.01\end{array}$ & $\begin{array}{l}1.42^{\mathrm{a}} \\
\pm 0.02\end{array}$ & $\begin{array}{c}1.37^{\mathrm{ab}} \\
\pm 0.005\end{array}$ & - \\
\hline
\end{tabular}

Dissolved oxygen concentrations averaged 4.38 to $5.21 \mathrm{mg} / \mathrm{l}$ among treatments, with no significant differences among means $(\mathrm{P}>0.05)$. The dissolved oxygen was maintained above acceptable levels recommended for Nile tilapia culture during the experimental period. Early morning $\mathrm{pH}$ values ranged from 7.63 to 7.67 , with no significant differences among treatments $(\mathrm{P}>0.05)$.

\subsubsection{Total ammonia and nitrite concentrations}

The results of the current study indicated that adding sucrose at $50 \%$ of daily ration inputs in biofloc tanks was suitable for bacterial metabolism and growth which resulted in reduced total ammonia (TAN) and nitrite (NO2$\mathrm{N})$ concentrations in water medium where fish were reared.

This is in agreement with Hari et al. (2006) and Asaduzzaman et al. (2008) who indicated that adding carbohydrate sources in biofloc tanks decreased TAN and $\mathrm{NO}_{2}-\mathrm{N}$ concentrations in culture medium. Mean values of total ammonia nitrogen (TAN) were within the acceptable range considered suitable for the cultivation of Nile tilapia $(0.6-1.02 \mathrm{mg} / \mathrm{l})$, with no significant differences observed among treatments $(\mathrm{P}>0.05)$.

Although fish were fed at 75 to $100 \mathrm{~g} / \mathrm{m}^{3} / \mathrm{day}$, total ammonia concentrations in biofloc tanks were less than $1.0 \mathrm{mg}$ TAN/l during the experimental period. Sucrose supplementation helped keep $\mathrm{NH}_{4}-\mathrm{N}$ under control according to Samocha et al. (2007). TAN concentrations remained below $0.52 \mathrm{mg} / \mathrm{l}$ during most of the experiment although fish should have excreted $2.25-3.0 \mathrm{mg}$ TAN/l/day.

Nitrite concentrations ranged from 0.35 to $0.51 \mathrm{mg} / 1$ among treatments. The concentrations of nitrite $\left(\mathrm{NO}_{2}-\mathrm{N}\right)$ remained within optimal levels recommended for the growth of Nile tilapia (Boyd, 1990), with no significant differences among treatments. The initial concentrations of nitrite were close to zero $(0.01$ $\left.-0.05 \mathrm{mg} \mathrm{NO}_{2} / \mathrm{l}\right)$, increasing over time to $0.6-$ $0.95 \mathrm{mg} \mathrm{NO} / 1$ by the end of the experiment. Nitrite is an intermediate product that is formed during nitrification and denitrification (Chuang et al., 2007). The data suggest that the autotrophic nitrifying bacterial community, mainly ammonia oxidizing bacteria, were 
abundant and converted ammonia to nitrite in all treatments.

\subsubsection{Nitrate and phosphate concentrations}

The nitrate concentrations accumulated over time during the experiment in all biofloc treatments. The overall mean values were approximately similar among treatments ranging from 29.8 to $46.0 \mathrm{mg} \mathrm{NO}_{3}-\mathrm{N} / \mathrm{l}$. Nitrate concentration up to $220 \mathrm{mg} \mathrm{NO}-\mathrm{N} / 1$ did not negatively affect survival and growth of aquatic animals according to Kuhn et al. (2010).

The biofloc treatments were characterized during the current study by the chemotrophic stage due to the nitrification process shown by the high concentration of nitrate $(29.8-46.0$ $\mathrm{mg} / \mathrm{l})$ observed at the end of study. Jatoba et al. (2014) indicated that the biofloc system is characterized by the transition from heterotrophic to autotrophic to chemotrophic stages due to the nitrification process, which results in an increased nitrate concentration with time.

The accumulation of $\mathrm{NO}_{3}-\mathrm{N}$ during the experimental period indicated suitable conditions for Nitrozomonas and Nitrobacter bacteria which are inhibited by shortage of oxygen and high organic contents in water (Okabe et al., 1996). The nitrite oxidizing bacteria which are slow to develop (Correia et al., 2014) with 72 hour doubling time, worked well in all biofloc treatments, producing nitrate at concentrations of 29.8 to $46.0 \mathrm{mg} \mathrm{NO3-} \mathrm{N/1}$ by the end of the experiment. Correia et al. (2014) observed nitrate concentration of 65.8 to $96.1 \mathrm{mg} / \mathrm{l}$ in biofloc tank when fish were fed $40 \%$ and $30 \%$ crude protein diet.

Averages of phosphate concentration in the biofloc treatments $\left(0.77\right.$ to $\left.1.29 \mathrm{mg} \mathrm{PO}_{4}-\mathrm{P} / \mathrm{l}\right)$ were slightly higher than that of the control treatment $\left(0.80 \mathrm{mg} \mathrm{PO}_{4}-\mathrm{P} / \mathrm{l}\right)$. However, no significant differences were observed in phosphate concentrations among the biofloc treatments due to the weekly and biweekly partial water renewal.

\subsubsection{Water turbidity and biofloc volume}

Biofloc volume (BFV) was nearly similar within and among biofloc treatments over time. The changing pattern over time within each treatment was not basically consistent. The biofloc treatments with higher feed input (100 g diet $/ \mathrm{m}^{3} /$ day) had biofloc volume $40.7-51.4 \mathrm{ml} / 1$ that did not differ significantly from those of the lower feed input treatments $(38.1-60.1 \mathrm{ml} / \mathrm{l})$. The increase of daily feed input from 75.0 $\mathrm{g} / \mathrm{m}^{3} /$ day to $100.0 \mathrm{~g} / \mathrm{m}^{3} /$ day did not affect biofloc volume in culture tanks due to the water renewal design.

The formation of biofloc can be achieved by constant aeration and agitation $\left(>100 \mathrm{w} / \mathrm{m}^{3}\right)$ of water column and by adding organic matter substrate $(\mathrm{C}: \mathrm{N}>10)$ which allows ammonium to be assimilated by heterotrophic bacteria and maintain high levels of suspended microbial flocs (Hargreaves, 2013). Water exchange has to be adopted to reduce toxic effects of accumulated inorganic nitrogen and dilute biofloc concentration in water (Gao et al., 2012).

During a preliminary experiment, it was observed that biofloc volume often exceeds 80 $\mathrm{ml} / \mathrm{l}$ without water renewal. Consequently, the design of the current experiment included testing the effect of partial water renewal at $50 \%$ of water volume in each tank at weekly and biweekly intervals in order to reduce excessive biofloc volumes in culture tank. Moreover, partial water renewal could be used to irrigate agricultural plant crops when integrated aquaculture and agriculture plans are desired in desert areas. The partial water renewal could also reduce toxic effect of accumulated nitrite $\left(\mathrm{NO}_{2}-\mathrm{N}\right)$ and nitrate $\left(\mathrm{NO}_{3}-\mathrm{N}\right)$ compounds.

\subsection{Growth performance and survival}

Growth and feed performances of Nile tilapia reared under different biofloc conditions are shown in Tables (2 and 3). Nile tilapia in the biofloc treatments grew well over the duration of the experiment as shown by the increasing average body weight with optimal feed conversion ratios (Table 2).

Nile tilapia reared under biofloc system had significantly lower $(\mathrm{P}<0.05)$ mean final weights $(55.8-67.9 \mathrm{~g} / \mathrm{fish})$ and specific growth rates (1.26 - 1.56\% per day) than those reared in the control treatment $(91.4 \mathrm{~g}$ /fish and $1.74 \%$ per day, respectively). However, all treatments had similar harvest volume (5.15 to $6.08 \mathrm{~kg}$ fish $/ \mathrm{m}^{3}$ ), with no significant differences among the biofloc treatments and the control treatment. This was due to the better survival rates observed in the biofloc treatments compared to the control treatment $(\mathrm{P}<0.05)$. In spite of the differences in growth rates, the higher protein efficiency ratios (2.14- 2.59) and the better food conversion ratios $(1.21-1.76: 1)$ observed in the biofloc treatments indicated that it is possible to use restricted feeding when fish are raised in biofloc tanks.

The biofloc provided additional protein source (bacterial protein) that supplemented the nutrition of tilapia. Fish in the biofloc tanks were 


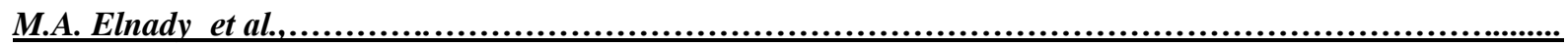

Table (2):Growth performance of Nile tilapia reared under different biofloc onditions.

\begin{tabular}{|c|c|c|c|c|c|}
\hline \multirow[b]{2}{*}{ Parameters } & \multicolumn{2}{|c|}{ 75grams diet $/ \mathrm{m}^{3}$} & \multicolumn{2}{|c|}{100 grams diet $/ \mathrm{m}^{3}$} & \multirow[b]{2}{*}{ control } \\
\hline & $\begin{array}{l}\text { Weekly } \\
\text { change }\end{array}$ & $\begin{array}{c}\text { Biweekly } \\
\text { change }\end{array}$ & $\begin{array}{l}\text { Weekly } \\
\text { change }\end{array}$ & $\begin{array}{l}\text { Biweekly } \\
\text { change }\end{array}$ & \\
\hline Initial weight (gram/fish & $\begin{array}{c}24.67^{\mathrm{ab}} \\
\pm 3.41\end{array}$ & $\begin{array}{c}24.72^{\mathrm{ab}} \\
\pm 1.04\end{array}$ & $\begin{array}{l}23.65^{b} \\
\pm 2.17\end{array}$ & $\begin{array}{c}26.60 \mathrm{ab} \\
\pm 3.64\end{array}$ & $\begin{array}{l}29.44^{\mathrm{a}} \\
\pm 1.05\end{array}$ \\
\hline Final weight (gram/fish) & $\begin{array}{l}55.85^{\mathrm{d}} \\
\pm 3.73\end{array}$ & $\begin{array}{l}58.88^{c} \\
\pm 2.67 \\
\end{array}$ & $\begin{array}{l}65.09^{b} \\
\pm 2.20\end{array}$ & $\begin{array}{l}67.95^{b} \\
\pm 3.38\end{array}$ & $\begin{array}{l}91.44^{\mathrm{a}} \\
\pm 7.07\end{array}$ \\
\hline Weight gain(g/fish) & $\begin{array}{l}31.18^{\mathrm{c}} \\
\pm 2.19\end{array}$ & $\begin{array}{c}34.16^{\mathrm{bc}} \\
\pm 1.87\end{array}$ & $\begin{array}{l}41.43^{b} \\
\pm 0.06\end{array}$ & $\begin{array}{l}41.35^{b} \\
\pm 6.03\end{array}$ & $\begin{array}{l}62.02^{\mathrm{a}} \\
\pm 7.60\end{array}$ \\
\hline Daily weight gain(g/fish/day) & $\begin{array}{l}0.47^{\mathrm{c}} \\
\pm 0.03\end{array}$ & $\begin{array}{l}0.52^{\mathrm{c}} \\
\pm 0.02 \\
\end{array}$ & $\begin{array}{c}0.63^{\mathrm{b}} \\
\pm 0.001\end{array}$ & $\begin{array}{l}0.63^{\mathrm{b}} \\
\pm 0.09\end{array}$ & $\begin{array}{l}0.95^{\mathrm{a}} \\
\pm 0.11 \\
\end{array}$ \\
\hline SGR (\%) & $\begin{array}{l}1.26^{\mathrm{b}} \\
\pm 0.13 \\
\end{array}$ & $\begin{array}{l}1.33^{\mathrm{b}} \\
\pm 0.03\end{array}$ & $\begin{array}{l}1.56^{\mathrm{ab}} \\
\pm 0.09\end{array}$ & $\begin{array}{l}1.45^{\mathrm{b}} \\
\pm 0.25 \\
\end{array}$ & $\begin{array}{r}1.74^{\mathrm{a}} \\
\pm 0.15 \\
\end{array}$ \\
\hline Stocking rate (numbers/tank) & 200 & 200 & 200 & 200 & 200 \\
\hline Fish harvest (numbers/tank) & $\begin{array}{l}200.00^{\mathrm{a}} \\
\pm 22.00\end{array}$ & $\begin{array}{l}176.00^{b} \\
\pm 19.00\end{array}$ & $\begin{array}{c}186.33^{\mathrm{a}} \\
\pm 8.50\end{array}$ & $\begin{array}{c}166.66^{\mathrm{ab}} \\
\pm 39.52\end{array}$ & $\begin{array}{l}135.00^{\mathrm{b}} \\
\pm 39.00\end{array}$ \\
\hline Survival (\%) & 100 & 88.0 & 93.1 & 83.3 & 67.5 \\
\hline
\end{tabular}

Table (3). Feed performance and harvest data of Nile tilapia reaed under different biofloc conditions.

\begin{tabular}{|c|c|c|c|c|c|}
\hline \multirow[b]{2}{*}{ Parameters } & \multicolumn{2}{|c|}{75 grams diet $/ \mathrm{m}^{3}$} & \multicolumn{2}{|c|}{100 grams diet $/ \mathrm{m}^{3}$} & \multirow[b]{2}{*}{ control } \\
\hline & $\begin{array}{l}\text { Weekly } \\
\text { change }\end{array}$ & $\begin{array}{l}\text { Biweekly } \\
\text { change }\end{array}$ & $\begin{array}{l}\text { Weekly } \\
\text { change }\end{array}$ & \begin{tabular}{|l} 
Biweekly \\
change
\end{tabular} & \\
\hline Initial biomass(kg/tank) & $\begin{array}{l}4.50^{\mathrm{a}} \\
\pm 0.00\end{array}$ & $\begin{array}{l}4.50^{\mathrm{a}} \\
\pm 0.00\end{array}$ & $\begin{array}{l}4.50^{\mathrm{a}} \\
\pm 0.00\end{array}$ & $\begin{array}{l}4.50^{\mathrm{a}} \\
\pm 0.00\end{array}$ & $\begin{array}{l}4.50^{\mathrm{a}} \\
\pm 0.00\end{array}$ \\
\hline Harvest biomass (kg/tank) & $\begin{array}{l}11.37^{\mathrm{a}} \\
\pm 0.46\end{array}$ & $\begin{array}{l}10.3^{\mathrm{a}} \\
\pm 0.65\end{array}$ & $\begin{array}{l}12.11^{\mathrm{a}} \\
\pm 0.14\end{array}$ & $\begin{array}{l}11.23^{\mathrm{a}} \\
\pm 2.11\end{array}$ & $\begin{array}{l}12.16^{\mathrm{a}} \\
\pm 2.65\end{array}$ \\
\hline Net biomass gain(kg /tank) & $\begin{array}{l}6.93^{\mathrm{a}} \\
\pm 0.46\end{array}$ & $\begin{array}{l}5.87^{\mathrm{a}} \\
\pm 0.65\end{array}$ & $\begin{array}{l}7.67^{\mathrm{a}} \\
\pm 0.14\end{array}$ & $\begin{array}{l}6.79^{\mathrm{a}} \\
\pm 2.11 \\
\end{array}$ & $\begin{array}{r}7.72^{\mathrm{a}} \\
\pm 2.65\end{array}$ \\
\hline Fish harvest $\left(\mathrm{kg} / \mathrm{m}^{3}\right)$ & $\begin{array}{l}5.68^{\mathrm{a}} \\
\pm 0.23\end{array}$ & $\begin{array}{l}5.15^{\mathrm{a}} \\
\pm 0.32\end{array}$ & $\begin{array}{l}6.05^{\mathrm{a}} \\
\pm 0.07\end{array}$ & $\begin{array}{l}5.61^{\mathrm{a}} \\
\pm 1.06\end{array}$ & $\begin{array}{r}6.08^{\mathrm{a}} \\
\pm 1.33\end{array}$ \\
\hline Feed input (kg/tank) & $\begin{array}{l}8.40^{\mathrm{c}} \\
0.00\end{array}$ & $\begin{array}{l}8.40^{\mathrm{c}} \\
\pm 0.00 \\
\end{array}$ & $\begin{array}{l}11.20^{\mathrm{b}} \\
\pm 0.00\end{array}$ & $\begin{array}{l}11.20^{\mathrm{b}} \\
\pm 0.00 \\
\end{array}$ & $\begin{array}{l}14.00^{\mathrm{a}} \\
\pm 0.00\end{array}$ \\
\hline FCR & $\begin{array}{l}1.21^{\mathrm{b}} \\
\pm 0.08\end{array}$ & $\begin{array}{l}1.43^{\mathrm{b}} \\
\pm 0.16\end{array}$ & $\begin{array}{l}1.45^{\mathrm{b}} \\
\pm 0.02\end{array}$ & $\begin{array}{l}1.76^{\mathrm{b}} \\
\pm 0.57 \\
\end{array}$ & $\begin{array}{r}1.97^{\mathrm{a}} \\
\pm 0.71\end{array}$ \\
\hline PER & $\begin{array}{l}2.59^{\mathrm{a}} \\
\pm 0.17\end{array}$ & $\begin{array}{l}2.23^{\mathrm{a}} \\
\pm 0.18\end{array}$ & $\begin{array}{l}2.14^{\mathrm{a}} \\
\pm 0.04\end{array}$ & $\begin{array}{l}1.90^{\mathrm{a}} \\
\pm 0.59\end{array}$ & $\begin{array}{r}1.72^{b} \\
\pm 0.59 \\
\end{array}$ \\
\hline
\end{tabular}


fed at 75 to $100 \mathrm{~g} / \mathrm{m}^{3} / \mathrm{day}$, consequently, fish in the biofloc treatments had lower growth rates due to restricted feeding. However, fish in the control treatment were fed at satiation at 125 gram. Therefore, the control treatment had higher growth rate, but with low survival and inferior FCR that negatively affected the harvest volume $/ \mathrm{m}^{3}$.

The biofloc treatments were more efficient in terms of feed conversion ratios and survival. The overall results produced similar harvest volume and biomass gain among the biofloc and the control treatments $(p>0.05)$. Consequently, the current results suggest that in the presence of biofloc, it is possible to restrict (reduce) feeding rates from satiation $\left(125 \mathrm{~g} \mathrm{diet} / \mathrm{m}^{3} /\right.$ day $)$ to restricted feeding (75 to $100 \mathrm{~g}$ diet $/ \mathrm{m}^{3} /$ day), without affecting harvest volume or survival rate. However, the duration of the growing season may be extended to compensate for the lower daily gain observed in the biofloc treatments.

Daily weight gain and SGR (\%) increased within the biofloc treatments with increasing feeding rate from 75 grams diet $/ \mathrm{m}^{3} /$ day $(0.47-$ $0.52 \mathrm{~g} \mathrm{/} \mathrm{fish/day} \mathrm{and} 1.26-1.33 \%$ per day, respectively ) to 100 grams diet $/ \mathrm{m}^{3} /$ day $(0.63$ $\mathrm{g} /$ fish/day and $1.45-1.56 \%$ per day, respectively).

The best daily weight gain $(0.95 \mathrm{~g} /$ fish/day) and SGR (\%) (1.74 \% per day) were obtained in the control treatment which was fed to satiation at $125 \mathrm{~g} \mathrm{diet} / \mathrm{m}^{3} /$ day, but with inferior FCR $(1.97: 1)$, reduced survival and similar harvest volume compared with the biofloc treatments.

At the end of the culture period, body weights of Nile tilapia differed significantly among treatments $(\mathrm{P}<0.05)$. Final body weight in the control treatment fed to satiation (91.4 g/fish) was significantly higher than those in the 100 grams biofloc treatments $(65.0-67.9 \mathrm{~g} / \mathrm{fish})$ and the $75 \mathrm{~g}$ biofloc treatments $(55.8-58.8 \mathrm{~g} /$ fish $)$. Increasing dietary inputs from $75 \mathrm{~g} \mathrm{diet} / \mathrm{m}^{3} /$ day to $100 \mathrm{~g}$ diet $/ \mathrm{m}^{3} /$ day within the biofloc treatments, improved final body weight at harvest by $15-16 \%$. However, total harvest volumes $\left(\mathrm{kg}\right.$ fish $/ \mathrm{m}^{3}$ ) were similar among the control and biofloc treatments (5.15 -6.08 $\mathrm{kg} / \mathrm{m}^{3}$ ), with no significant differences among means $(\mathrm{P}>0.05)$. This was due to the better FCR and improved survival in the biofloc treatments compared to those of the control. Since the control treatment was fed to satiation, feed efficiency (1.97: 1) was less than those of the biofloc treatments $(1.21-1.45: 1)$ where feeding was restricted to $75.0-100.0 \mathrm{~g} \mathrm{diet} / \mathrm{m}^{3} /$ day.

The productivity of fish $\left(\mathrm{kg}\right.$ harvest $/ \mathrm{m}^{3}$ ) ranged $5.15-6.08 \mathrm{~kg}$ fish $/ \mathrm{m}^{3}$ among treatments, with harvest density 67 to 100 fish per cubic meter of water. The biofloc treatments were able to produce 5.15 to $6.05 \mathrm{~kg}$ fish $/ \mathrm{m}^{3}$ at harvest time compared to that of the control treatment $\left(6.08 \mathrm{~kg}\right.$ fish $\left./ \mathrm{m}^{3}\right)$, with no significant differences among treatments $(\mathrm{P}>0.05)$. Fish harvest in the biofloc treatments ranged 83 to 100 fish per cubic meter of water, which was better than that of the control $\left(67 \mathrm{fish} / \mathrm{m}^{3}\right)$, although stocking densities were the same among all treatments at the start of the experiment.

Survival rates in biofloc treatments $(83.3-$ $100 \%)$ were significantly higher than that of the control treatment $(67.5 \%)$. Biofloc provided supplemental nutrition for Nile tilapia as wells as abundant natural microbes and bioactive compounds. The abundant natural microbes and bioactive compounds could exert positive effect on the physiological health of aquatic animals in biofloc culture systems (Ju et al., 2008a,b ; Xu and Pan, 2012).

At the end of the growth period, Nile tilapia harvested from the biofloc treatments ranged 166 to 200 fish per tank, while those harvested from the control treatment averaged 135 fish per tank. Survival rate increased with the rate of water renewal in the biofloc treatments. The high survival rates in the biofloc treatments were related to its better water quality according to Crab et al. (2012) and Wasielesky et al. (2013). Biofloc systems contributed to the rapid growth (Emerenciano et al., 2012 a,b and Viau et al., 2012), better survival (Yta et al.,2004) and reduced production costs (Wasielesky et al., 2013) through increasing the number of crops in temperate areas. Wasielesky et al. (2013) indicated that excessive increase in stocking density may decrease growth rate.

\subsection{Feed performance}

Feeding fish at $100 \mathrm{~g} \mathrm{diet} / \mathrm{m}^{3} /$ day yielded similar harvest volume compared to those fed 75 g diet $/ \mathrm{m}^{3} /$ day. Under the current experimental conditions, the lowest cost per kilogram of Nile tilapia produced was observed when feeding at $75 \mathrm{~g} \mathrm{diet} / \mathrm{m}^{3} /$ day with weekly partial water renewal in biofloc tanks. In general, feed conversion ratios were better in biofloc tanks under weekly water renewal compared to those of the biweekly water renewal at the same feed input per day. 
Feed conversion ratios averaged 1.21- 1.43:1 in the 75 grams diet $/ \mathrm{m}^{3}$ treatments, being better than those of the 100 grams diet $/ \mathrm{m}^{3}$ treatments (1.45 -1.76 : 1 ). The biofloc treatments had better FCR ratios than the control treatment (1.97: 1).

Ballester et al. (2010) reported that dietary protein level can be reduced by $10 \%$, without affecting growth performance of shrimp when reared in biofloc system. Xu and Pan (2014) pointed out that biofloc not only maintained water quality suitable for shrimp culture but also supplemented additional source of protein, resulting in high survival and similar growth performance.

The biofloc could provide additional source of protein (bacterial protein) necessary for aquatic animals nutrition which adds up to protein inputs (Ballester et al., 2010 ; Decamp et al., 2002 ; Hari et al., 2004). Biofloc systems provide fish with bacterial matter which is a source of protein nutrition and bioactive compounds that improve digestion ( $\mathrm{Ju}$ et al., 2008 a,b ; Xu and Pan, 2012). Moreover, the biofloc technology involves high production rate and feed protein recycling (Crab et al., 2012; Little et al., 2008).

The nutritional composition of the bioflocs improved the nutritional efficiency of fish and is considered a valuable food source (Azim and little, 2008 ; Luo et al., 2013). Nile tilapia can feed on biofloc particles in tank water, consequently, increasing the efficiency of protein utilization in the biofloc treatments compared to the control treatment. Biofloc can be an important feed supplement in shrimp and tilapia diets, improving digestion and protein efficiency (Otoshi et al., 2011; Xu et al., 2012 ; Wasielesky et al., 2013). The current study indicated the importance of natural food (Bacterial community) in the improvement of feed utilization under intensive aquaculture conditions.

All biofloc treatments produced harvest volumes (productivity) similar to that of the control treatment (5.15 to $\left.6.08 \mathrm{~kg} / \mathrm{m}^{3}\right)$. Moreover, feed conversion ratios, PER values and economic efficiencies of the biofloc treatments were better than those of the control treatment.

Water pumping costs of the control treatment was 6-12 times $\left(6 \mathrm{~m}^{3} /\right.$ tank/week) compared to those of the biofloc treatments (0.5$1 \mathrm{~m}^{3} /$ tank/week). Consequently, the biofloc system is more suitable in desert aquaculture in terms of water consumption needed to produce fish under limited water resources and high pumping costs. Currently, water pumping costs in desert areas in Egypt range from 0.25 to 0.5 L.E. $/ \mathrm{m}^{3}$ of water which needed to be used efficiently in integrated agriculture systems.

The natural food offered through the growth of heterotrophic bacteria provided high-quality feed supplement rich in crude protein to aquatic animals (Emerenciano et al., 2012; Wasielesky et al., 2013), consequently, improved feed utilization and better FCR are expected (Wasielesky et al., 2006). Better FCR of Nile tilapia in the biofloc treatments indicated that tilapia had high ability to graze on bacterial community under restricted feeding.

\section{Conclusion}

This study investigated the effects of restricted feeding and water renewal rates on growth and feed efficiency of Nile tilapia. The results indicated that the biofloc treatments were more efficient in terms of FCR and PER values due to feed restriction to 75 to $100 \mathrm{~g}$ diet $/ \mathrm{m}^{3} /$ day. The control treatment which was fed to satiation at $125 \mathrm{~g} \mathrm{diet} / \mathrm{m}^{3} /$ day produced better final body weight and daily weight gain with less feed efficiency, reduced survival rates and higher pumping costs.

\section{REFERENCES}

Asaduzzaman M., Wahab M.A., Verdegem M.C.J., Huque S., Salam M.A. and Azim M.E. (2008). C/N ratio control and substrate addition for periphyton development jointly enhance freshwater prawn Macrobrachium Rosenberger production in ponds. Aquacult., 280:117123.

Azim M.E. and Little D.C. (2008). The biofloc technology (BFT) in indoor tanks: water quality, biofloc composition and growth and welfare of Nile tilapia (Oreochromis niloticus). Aquacult., 283:29-35.

Ballester E.L.C., Abreu P.C., Cavalla R.O., Emerenciano M., Abreu L. and Wasielesky W. (2010). Effect of practical diets with different protein levels on the performance of Farfantepenaeus paleness juveniles nursed in a zero exchange suspended microbial flocs intensive system. Aquacult. Nutr., 16: 163-172.

Boyd C.E. (1990). Water quality in ponds for aquaculture. Alabama Agricultural Experiment Station. Auburn Univerisity Alabama, 482p. 
Boyd C.E. and Tucker C.S. (1992). Water quality and pond soil analyses for aquaculture. Alabama Agriculture Experiment Station. Auburn University, Alabama, USA.

Brune D., Schwartz G., Eversole A., Collier J. and Scheduler T. (2003). Intensification of pond aquaculture and high rate photosynthetic systems. Aquacult. Eng., 28: 65-86.

Chuang H.P., Ohashi A., Imachi H., Tendulkar M. and Harada H. (2007). Effective partial nitrification to nitrite by down-flow hanging sponge reactor under limited oxygen condition. Water Res.,41:295302.

Correia E.S., Wikenfeld J.S., Morris T.M. (2014). Intensive nursery production of the pacific white shrimp Litopenaeus vannamei using two commercial feeds with high and low protein content in a biofloc -dominated system. Aquacult. Eng., 59:48-54.

Crab R., Defoirdt T., Bossier P., Verstraete W. (2012). Biofloc technology in aquaculture: beneficial effects and future challenges. Aquacult., 356-357: 351-356.

Danaher J.J., Shultz R.C. and Rakocy J.E. (2011). Evaluation of two textiles with or without polymer addition for dewatering from an intensive biofloc production system. J. World Aquacult. Soc.,Vol.42: 66-72.

De Schryver P. and Verstraete W. (2009). Nitrogen removal from aquaculture pond water by heterotrophic nitrogen assimilation in lab-scale sequencing batch reactors. Biores. Tech., 100: 1162-1167.

Decamp O., Conquest L., Forster I. and Tacon A.G.J. (2002). The nutrition and feeding of marine shrimp within zero-water exchange aquaculture production system: role of Eukaryotic microorganisms. In: Lee, C.S., O’Brien, P. (eds.), Microbial Approaches to Aquatic Nutrition within Environmentally Sound Aquaculture Production Systems. World Aquaculture Society, Baton Rouge, USA, pp. 79-86.

Duncan D.B. (1955). Multiple range and multiple F tests . Biometrics , 11:1-42.

Ebeling J.M., Timmons M.B. and Bisogni J.J. (2006). Engineering analysis of the stoichiometry of photoautotrophic, autotrophic, and heterotrophic removal of ammonia-nitrogen in aquaculture systems. Aquacult., 257: 346-358.

Ekasari J., Zairin M.J., Putri D.U., Sari N.P., Surawidjaja E.H. and Bssier p. (2013). Biofloc-based reproductive performance of Nile tilapia Oreochromis niloticus L.brood stock. Aquacult.Res.,2013: 1-4.

Emerenciano M., Ballester E.L.C., Cavalla R.O. and Wasielesky W. (2011). Effect of biofloc technology (BFT) on the early post larval stage of pink shrimp Farfantepenaeus paleness: growth performance, floc composition and salinity stress tolerance. Aquacult. Int., 19 (5):891-901.

Emerenciano M., Cuzon G., Goguenheim J., Gaxiola G., AQUACOP, (2012 a ). Floc contribution on spawning performance of blue shrimp Litopenaeus stylirostris. Aquacult. Res., 44: 75-85.

Emerenciano M., Ballester E.L.C., Cavalli R.O. and Wasielesky W. (2012 b). Biofloc technology application as a food source in a limited water exchange nursery system for pink shrimp Farfantepenaeus brasiliensis (Laetrile, 1817). Aquacult. Res., 43:447-457.

FAO - Fisheries and Aquaculture Department (2012). The State of World Fisheries and Aquaculture. Food and Agriculture Organization of the United Nations, Rome.

Gao L., Shan H.W., Zhang T.W., Bao W.Y. and Ma S. (2012). Effects of carbohydrate addition on Litopenaeus vannamei intensive culture in a zero-water exchange systems. Aquacult., 342-343:89-96.

Hargreaves J. A. (2006). Photosynthetic suspended-growth systems in aquaculture. Aquacult. Eng., 34:344-363.

Hargreaves J.A. (2013). Biofloc production system for aquaculture. Southern Regional Aquaculture Center (SRAC) Publication No. 4503.

Hari B., Kurup B.M., Varghese J.T., Schrama J.W. and Verdegem M.C.J. (2004).

Effects of carbohydrate addition on production in extensive shrimp culture systems. Aquacult., 241: 179-194.

Hari B., Kurup B.M., Varghese J.T., Schrama J.W. and Verdegem M.C.J. (2006). The effect of carbohydrate addition on water quality and the nitrogen budget in extensive shrimp culture systems. Aquacult., 252:248-263. 
Jatoba A. , Da Silva B.C. , Da Silva J.S. ,Vieira F.N. , Mourino J.L.P. and Seiffert W.Q. (2014). Protein levels for Litopenaeus vannamei in semi-intensive and biofloc systems. Aquacult., 432:365-371.

Ju Z.Y., Forster I., Conquest L. and Dominy W. (2008a). Enhanced growth effects on shrimp (Litopenaeus vannamei) from inclusion of whole shrimp floc or floc fractions to a formulated diet. Aquacult. Nutr., 14: 533-543.

Ju Z. Y., Forster I., Conquest L., Dominy W., Kuo W. C. and Horgen F. D. (2008b). Determination of microbial community structures of shrimp floc cultures by biomarkers and analysis of floc amino acid profiles. Aquacult. Res., 39: 118-133.

Kuhn D.D., Lawrence A.L., Boardman G.D., Patnaik S., Marsh L. and Flick G.J. (2010). Evaluation of two types of bioflocs derived from biological treatment of fish effluent as feed ingredients for Pacific white shrimp, Litopenaeus vannamei. Aquacult., 303: 28-33.

Little D.C., Murray J.F., Azim M.E., Leschen W., Grady K., Young J. and Watterson A. (2008). Warm-water fish production in the UK: limits to green growth?. Trends in Food Sci. and Tech., 19: 255-264.

Luo G.Z., Pan Y.F. and Tan H.X. (2013). Inorganic nitrogen dynamics in sequencing batch reactors using bioflocs technology to treat aquaculture sludge. Aquacult. Eng., 52: 73-79.

Ogello E.O.,Musa S.M., Aura C.M.,Abwao J.A. and Munguti J.M. (2014). An appraisal of the feasibility of tilapia production in ponds using biofloc technology :A review, International J. Aquatic Sci., 5(1): 21-39.

Okabe S., Oozawa Y., Hirata K. and Watanabe Y. (1996).Relationship between population dynamics of nitrifies in biofilms and reactor performance at various C: N ratios. Water Res.,30: 15631572.

Otoshi C.A., Moss D.R. and Moss S.M.( 2011). Growth - enhancing effect of pond water on four size classes of Pacific white shrimp, Litopenaeus vannamei. J. World Aquacult. Soc., 42: 417-422.

Rakocy J. E., Bailey D. S., Thoman E. S. and Shultz R. C. (2004). Intensive tank culture of tilapia with a suspended, bacterialbased, treatment process. Pages 584-596 in R. B. Bolivar, G. C. Mair, and K.
Fitzsimmons (eds). Proceedings of the 6th International Symposium on Tilapia in Aquaculture, volume 2. Philippine International Convention Center, Manila, Philippines, September 12-16.

Samocha T.M., Patnaik S., Speed M., Ali A.M., Burger J.M., Almeida R.V., Ayub Z., Harisanto M., Horowitz A. and Brock D.L. (2007). Use of molasses as carbon source in limited discharge nursery and grow-out systems for Litopenaeus vannamei. Aquaculture Engineering, 36: 184-191.

Schrader K.K., Green B.W. and Perch Bacher (2011).Development of phytoplankton communities and common off-flavors in abiofloc technology system used for the culture of channel catfish (Ictalurus punctatus) .Aquacult. Eng. ,45:118-126.

SPSS Inc. (1997). Statistical analysis software package. SPSS production Facility Release 8.0, USA.

Supono S., Hutabarat J., Prayitno S.B. and Darmanto Y.S. (2013).The effect of different $\mathrm{C} ; \mathrm{N}$ of media on the content of polyhydroxybutyrate in biofloc inoculated with bacterium Bacillus cereus. J. Coastal Develop., 16(2):114-120.

Viau V. E., Souza D. M., Rodriguez E. M., Wasielesky W., Abreu P. C. and Ballester E. L. C. (2012). Biofilm feeding by post larvae of the pink shrimp Farfantepenaeus brasiliensis (Decapoda, Penaeidae). Aquacult. Res., 44:783-794.

Wasielesky W., Atwood H., Stokes A., Browdy C.L. (2006). Effect of natural production in a zero exchange suspended microbial floc based super-intensive culture system for white shrimp Litopenaeus vannamei. Aquaculture, 258: 396-403.

Wasielesky W., Froes C., Foes G., Krummenauer D., Lara G. and Poersch L. (2013). Nursery of Litopenaeus vannamei reared in a biofloc system: The effect of stocking densities and compensatory growth, J. Shellfish Res., 32(3):799-806.

Xu W.J. and Pan L.Q. (2012). Effects of bioflocs on growth performance, digestive enzyme activity and body composition of juvenile Litopenaeus vannamei in zero-water exchange tanks manipulating $\mathrm{C} / \mathrm{N}$ ratio in feed. Aquacult., 356-357: 147-152. 
$\mathrm{Xu}$ W.J. and Pan L.Q. (2014). Evaluation of dietary protein level on selected parameters of immune and antioxidant systems, and growth performance of juvenile Litopenaeus vannamei reared in zero-water exchange biofloc-based culture tanks. Aquacult., 426: 181-188.
Yta A. G., Rouse D. B. and Davis D. A. (2004). Influence of nursery period on the growth and survival of Litopenaeus vannamei under pond production conditions. J. World Aqua cult. Soc., $35: 357-365$.

تأثير التظذية المحدودة فى نظام البيوفلوك والتجديد الجزئى للمياه على جودة المياه وأداء النمو للبلطي النيلي

$$
\begin{aligned}
& \text { محمد النادى احمد - رشا خالد عبد الواحد ـ امل فرج يونس } \\
& \text { قسم الإانتاج الحيو انى ـ كلية الزر اعة ـ جامعة القاهرة ـ الجيزة ـ مصر }
\end{aligned}
$$

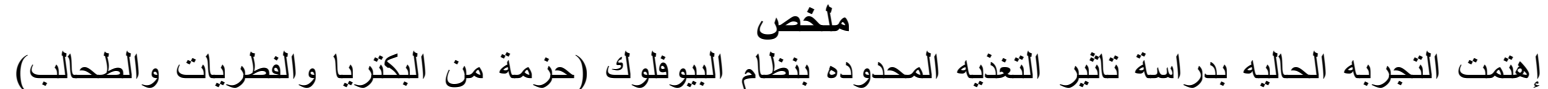

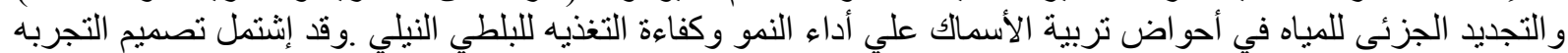

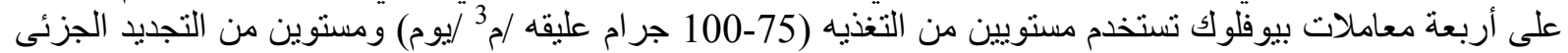

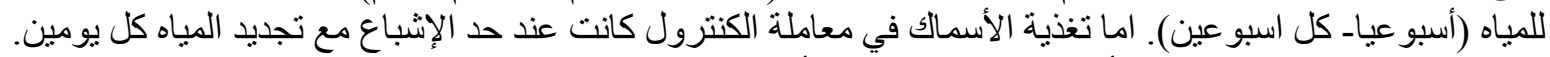

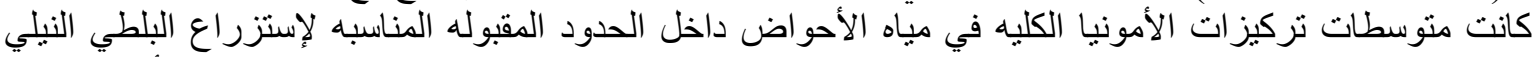

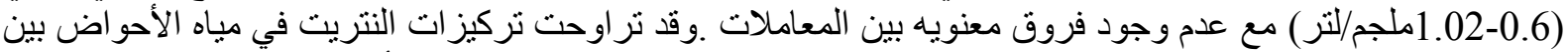

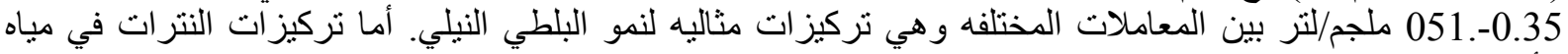

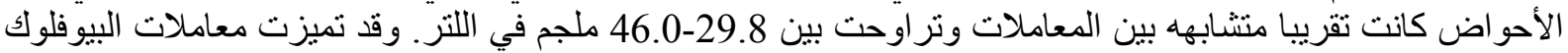

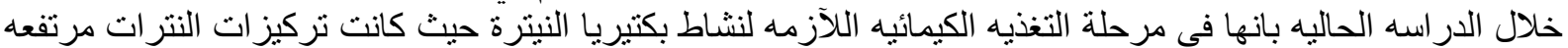

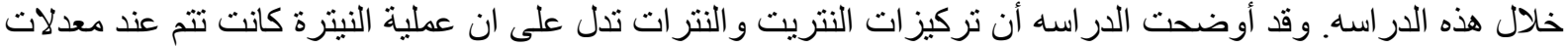

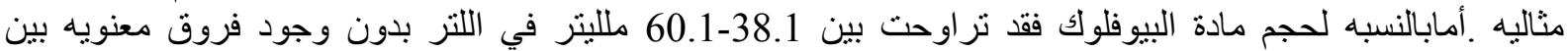

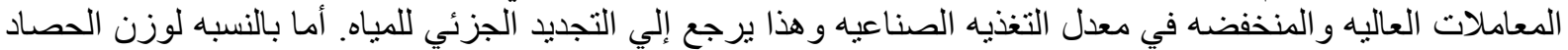

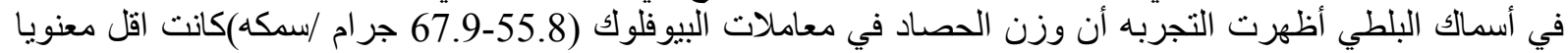

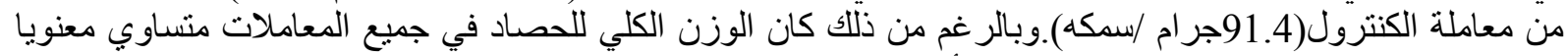

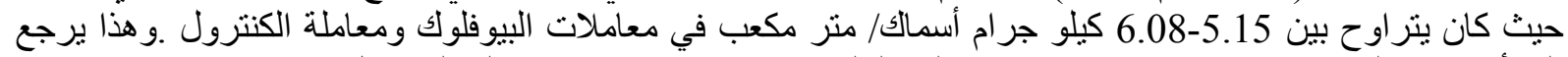



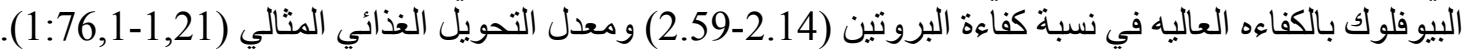

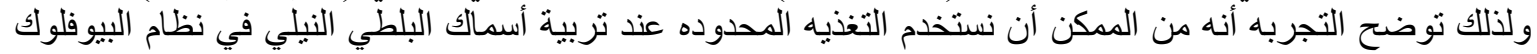

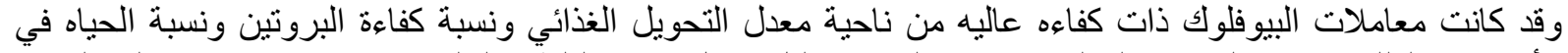

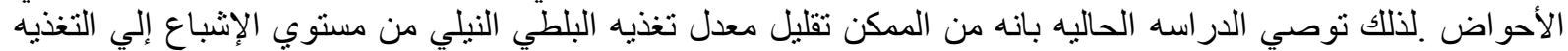

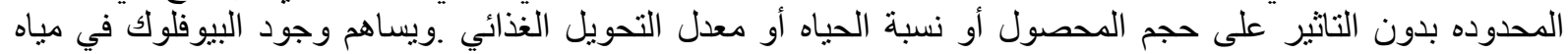

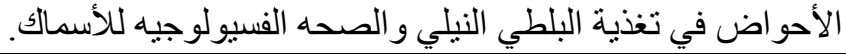

المجلة العلمية لكلية الزراعة - جامعة القاهرة - المجلد (66) العدد الثالث (يوليو 2015): 233-223 ـ الفيل 